\title{
A new genus Austrohondaella (Bryopsida, Hypnaceae) from Australasia
}

\author{
Zen Iwatsuki', H. P. Ramsay² and A. J. Fife ${ }^{3}$ \\ ${ }^{1}$ The Hattori Botanical Laboratory, Okazaki Branch, 10-3 Mutsuna-shin-machi, Okazaki-shi, \\ Aichi-ken 444-0846, Japan. \\ ${ }^{2}$ National Herbarium of New South Wales, Royal Botanic Gardens, Sydney 2000 NSW Australia. \\ ${ }^{3}$ Manaaki Whenua - Landcare Research, P.O. Box 40, Lincoln 7640, New Zealand. \\ Author for correspondence: hpramsay@ozemail.com.au
}

\begin{abstract}
The taxonomic position of Isopterygium limatum (Hook.f. \& Wilson) Broth. has been reevaluated. Some morphological characters, such as cylindric capsules, conic and non-rostrate opercula, well-differentiated annuli, pseudoparaphyllia shape, and axillary, papillose rhizoids suggest that the species should be excluded from the genus Isopterygium. A new genus, Austrohondaella Z.Iwats., H.P.Ramsay \& Fife is therefore described here for Isopterygium limatum. This new genus should be classified in the family Hypnaceae.
\end{abstract}

\section{Introduction}

During studies on the genus Isopterygium for the floras of Australia and of New Zealand, it was noted separately by Fife and Iwatsuki that certain characteristics such as the erect capsule and operculum form, presence of an annulus, form of pseudoparaphyllia, and axillary and papillose rhizoids in Isopterygium limatum were not characteristic of the genus Isopterygium as outlined by Iwatsuki $(1970,1987)$ and Iwatsuki and Ramsay (2009). The common morphological features such as lanceolate leaves with a usually entire leaf margin, papillose axillary rhizoids and a differentiated annulus suggest that it might be a species of Isopterygiopsis (Fife in Seppelt 2004: 186). However, other features of I. limatum such as its erect capsules, bluntly conic opercula, narrowly foliose pseudoparaphyllia, etc are not consistent with this suggestion.

Sporophytic characters of I. limatum are quite different from those of both Isopterygium tenerum, the lectotype species for the genus Isopterygium, and I. albescens which is widely distributed in Australasia, eastern Asia and Oceania. In the genus Isopterygium, erect and almost symmetrical capsules occur only in I. limatum. However, erect symmetrical capsules are not rare in Hypnaceae; for example, some species of Hondaella, Platygyrium, Pylasia. Species of Isopterygium s.s., including I. albescens and I. tenerum, lack a differentiated annulus and have apiculate or obliquely short-rostrate opercula while I. limatum has both a well differentiated and deciduous annulus of 2 or 3 rows of cells and a bluntly conic operculum. 
Some gametophytic characters of Isopterygium limatum are also clearly anomalous in the genus Isopterygium, according to the criteria set out by Iwatsuki (1987) and cited in Ireland (1991). Species of Isopterygium have filamentous pseudoparaphyllia, while I. limatum has narrowly foliose pseudoparaphyllia, similar to those of species of Ectropothecium. The leaves of I. limatum are characteristically strongly secund giving the species something of the appearance of Hypnum, while those of Isopterygium are usually more or less complanate, erect spreading or only moderately secund. Rhizoids commonly arise on stems between leaf insertions and are smooth in most species of Isopterygium whereas they are axillary and papillose in I. limatum. These differences are significant enough to require a new genus for this interesting moss, and we propose the name Austrohondaella.

The new monotypic genus Austrohondaella shares some common characters with Hondaella, a genus of Hypnaceae recorded from eastern Asia (Japan, China, Korea, Laos, Myanmar, Thailand, and Russia). Illustrations of the type species of Hondaella, H. aulacophylla Dixon \& Sakurai (= H. brachytheciella (Broth. \& Paris ) Ando) are available in Sakurai (1938) and Noguchi (1994). Species of Hondaella and Austrohondaella have erect capsules, similar leaf shape, entire leaf apices, hypnaceous peristomes, etc. However, the pseudoparaphyllia of Hondaella are much larger, and wider, than those of Austrohondaella. Moreover, the annulus is not differentiated, and leaves are truncate at the base in Hondaella.

\section{Austrohondaella Z.Iwats., H.P.Ramsay \& Fife, gen. nov.; fam. Hypnacearum}

Plantae mediocres dioicae; caulis prostratus; stratum corticale e cellulis incrassatis compositum; rhizoidea papillosa axillariaque; folia anguste ovato-lanceolata; nervis binis brevissimus; pseudoparaphyllia anguste foliosa; alae foliorum non decurrentes; cellulae foliorum angustissime prosenchymaticae; thecae ovoideae; annulus distinctus; operculum conicum.

Type species: Hypnum limatum Hook.f. \& Wilson, Fl. Antarct. 2 (Suppl.): 545 (1847); Isopterygium limatum (Hook.f. \& Wilson) Broth., Nat. Pflanzenfam. 1(3): 1080 (1908).

Etymology: the generic name reflects the morphological similarities to the Asian genus Hondaella and the Australian/New Zealand distribution of the type species.

Plants dioicous. Stems creeping, irregularly branched, epidermal cells small and more or less thick-walled in cross-section; pseudoparaphyllia narrowly foliose, base 2 or 3 cells wide. Rhizoids axillary, red, papillose. Leaves narrowly lanceolate, often falcate to falcate-secund, base rounded, not decurrent; upper portion of leaf gradually narrowed to piliferous apex; costa weak and short, often absent; cells in median portion of lamina linear to subvermicular; basal cells shorter. Perichaetia lateral on stems; perichaetial leaves lanceolate, entire, ecostate with apex narrowly acute. Setae long exserted; capsules cylindrical, erect, mostly symmetrical, sometimes slightly asymmetrical; operculum bluntly conic, apex obtuse; annulus well developed; peristome teeth hypnaceous.

Austrohondaella limata (Hook.f. \& Wilson) Z.Iwats., H.P.Ramsay \& Fife, comb. nov.

Hypnum limatum Hook.f. \& Wilson, Fl. Antarct. 2 (Suppl.): 545 (1847). Type: Campbell's Island, Antarct. Exp. 1839-1843, J. D. Hooker; holotype BM (n.v.); isotype: NY. Isopterygium limatum (Hook.f. \& Wilson) Broth., Nat. Pflanzen. 1(3): 1080 (1908).

Hypnum terrae-novae Brid. var. australe Hook.f. \& Wilson, Fl. Antarct. 1: 142 (1845). 
Ectropothecium australe (Hook.f. \& Wilson) A.Jaeger, Ber. S. Gall. Naturw. Ges. 187778: 260 (1880) nom. illeg. incl. spec. prior.

Leskea amblyocarpa Hampe, Linnaea 30: 638 (1860). Type: Victoria, Apollo Bay, F. Mueller 50; holotype: BM. Isopterygium amblyocarpum (Hampe ) Broth., Nat. Pflanzenfam. 1(3): 1080 (1908). syn. nov.

Isopterygium acuminatum Bosw., J. Bot. 30: 99 (1892). Type: Tasmania, Glen Rae, 1891, W.A. Weymouth [555]; holotype: HO 73037; isotype: NY. syn. nov.

Illustrations: Hooker (1847, Plate LXI, fig. IV, as Hypnum terrae-novae); Sainsbury (1955, Plate 74, fig 3, as Isopterygium limatum); Seppelt (2004, fig. 74, as Isopterygium limatum).

Plants dioicous, yellow or golden-green, glossy, forming dense mats. Stems creeping, 1-2 cm long, irregularly branched; branches short, usually up to $5 \mathrm{~mm}$ long. Crosssections of stem round to more or less triangular, $0.1-0.2 \mathrm{~mm}$ in diam., epidermal cells small and more or less thick-walled, central strand present but often weak. Pseudoparaphyllia narrowly foliose, 2-4 cells wide at base. Rhizoids axillary, restricted to lower stems near base of branches, red, papillose. Leaves narrowly lanceolate to ovatelanceolate, secund and usually falcate, $1.0-1.5(-1.8) \mathrm{mm}$ long, $0.25-0.75 \mathrm{~mm}$ wide at base, base rounded, not decurrent, slightly concave; upper portion of leaf tapering evenly, narrowed to acuminate to piliferous apices; costa weak and double or often absent; margin entire; cells in median portion of lamina linear to subvermicular, 60 $120 \mu \mathrm{m}$ long, 5-8 $\mu \mathrm{m}$ wide, narrow at both ends, moderately thick-walled, not porose; cells at base of leaves wider and shorter, becoming porose; alar cells not differentiated. Propagules, when present, axillary and filamentous or \pm fusiform.

Perichaetia lateral on stems; perichaetial leaves lanceolate, narrowly acute at apices, to $1.7 \mathrm{~mm}$ long, $0.38 \mathrm{~mm}$ wide; ecostate, entire; laminal cells elongate and moderately thick-walled. Calyptra large, cucullate, c. $3 \mathrm{~mm}$ long. Setae 1.0-1.5 cm long, reddish brown. Capsules cylindrical, erect, often slightly to clearly asymmetrical, urn about $2 \mathrm{~mm}$ long; operculum bluntly conic; annulus well developed, deciduous; exothecial cells rectangular, 25-50 $\mu \mathrm{m}$ long, c. $20 \mu \mathrm{m}$ wide, moderately thin-walled. Peristome double, hypnaceous; outer teeth c. $1 \mathrm{~mm}$ long; endostome segments a little shorter than outer teeth; cilia 1 or 2, nodose, equal to the segments or rudimentary. Spores spherical, $10-18 \mu \mathrm{m}$ in diam., smooth. No chromosome number recorded. Figs 1-4.

Distribution: Australia (New South Wales (alpine), Victoria, Tasmania and Macquarie Is) and New Zealand (North, South, Stewart, Auckland and Campbell Is.). In Australia Austrohondaella occurs in scattered pure and dense mats on dolerite karst and also on basalt where it is found on moist exposed rock faces and in crevices. Also, it is occasionally epiphytic on semi-shaded tree trunks (e.g. Acacia, Pomaderris and tree ferns) and on fallen logs in disturbed Nothofagus or wet sclerophyll forest. On the mainland it occurs from $80-1700 \mathrm{~m}$, while on the island of Tasmania is recorded from 20-1000 m. In New Zealand it occurs in scattered or dense mats primarily on mesic or rather dry rock, but in the northern and southern portions of its range it also occurs on tree trunks. It is best developed in montane to alpine vegetation. Austrohondaella limata occurs on a wide range of rock types but is most frequent on limestone and marble; it occurs less frequently on greywacke, basalt, conglomerate, granite, diorite and on humus. When epiphytic at the extremities of its range the host species include the gymnosperms Prumnopitys taxifolia and Dacrydium cupressinum, as well as 


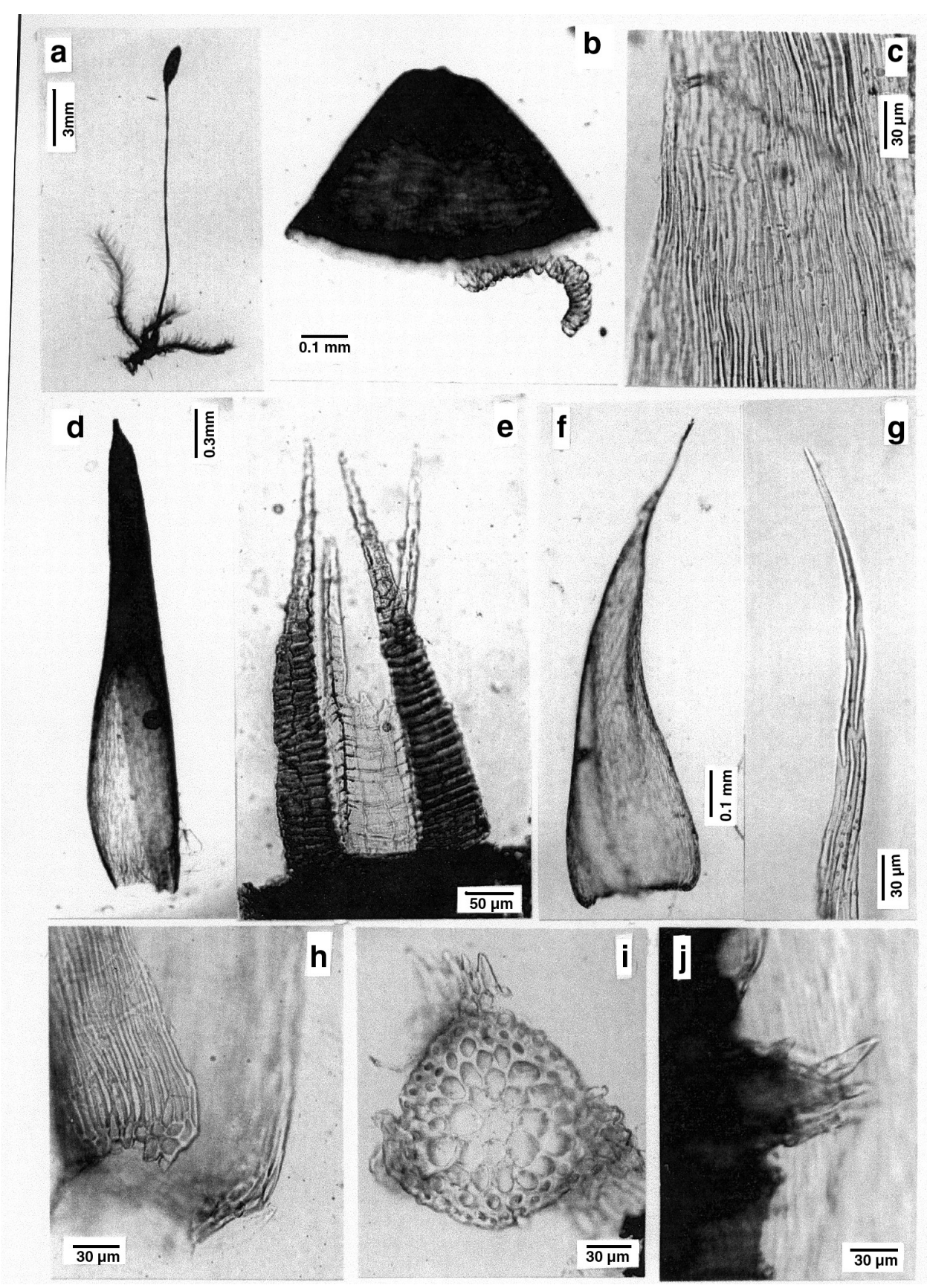

Fig. 1. Austrohondaella limata. a, type plant of Hypnum limatum with sporophyte; b, operculum with a part of annulus; c, median laminal cells of type; $d$, calyptra; e, peristome teeth and rudimentary cilia; $\mathbf{f}$, a leaf; $\mathbf{g}$, apex of leaf; $\mathbf{h}$, cells at base of leaf; $\mathbf{i}$, cross-section of stem; j, pseudoparaphyllia. (a, c, f, g, i and j from the isotype of Hypnum limatum in NY; b, d, e and h. from H. Streimann 58986 in NICH; all photographs by Z. Iwatsuki). 

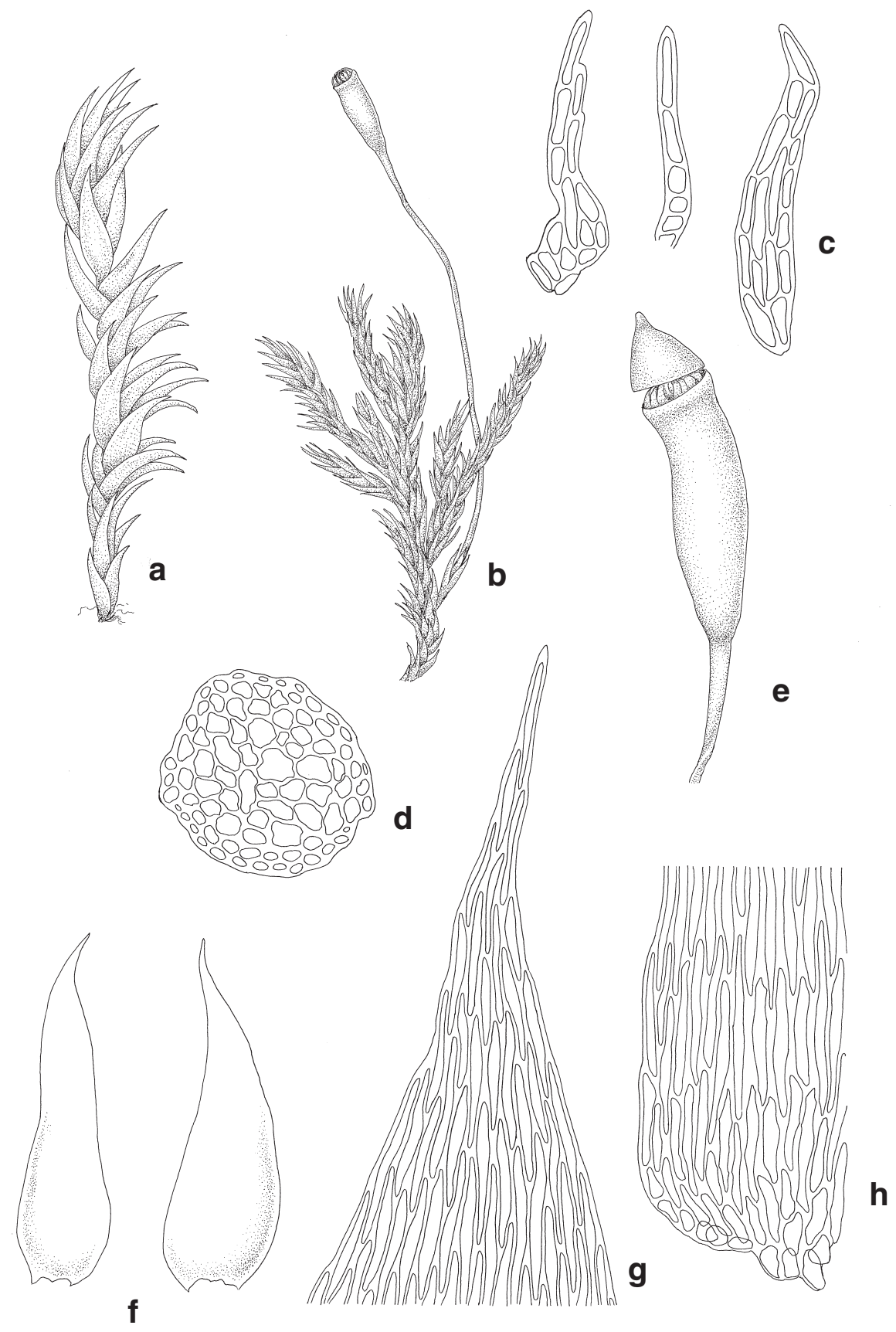

Fig. 2. Austrohondaella limata. a, sterile shoot; b, portion of fertile plant; c, pseudoparaphyllia; d, stem in cross section; e, moist capsule with operculum; f, stem leaves; $\mathbf{g}$, apex of stem leaf; h, alar cells of stem leaf. (a, b, d-h from J. Child 6212 ex Otago Peninsula, N.Z. (CHR 429281); c from A.J. Fife 7546 ex Mt Arthur range (CHR 438862); drawn by Rebecca Wagstaff). 


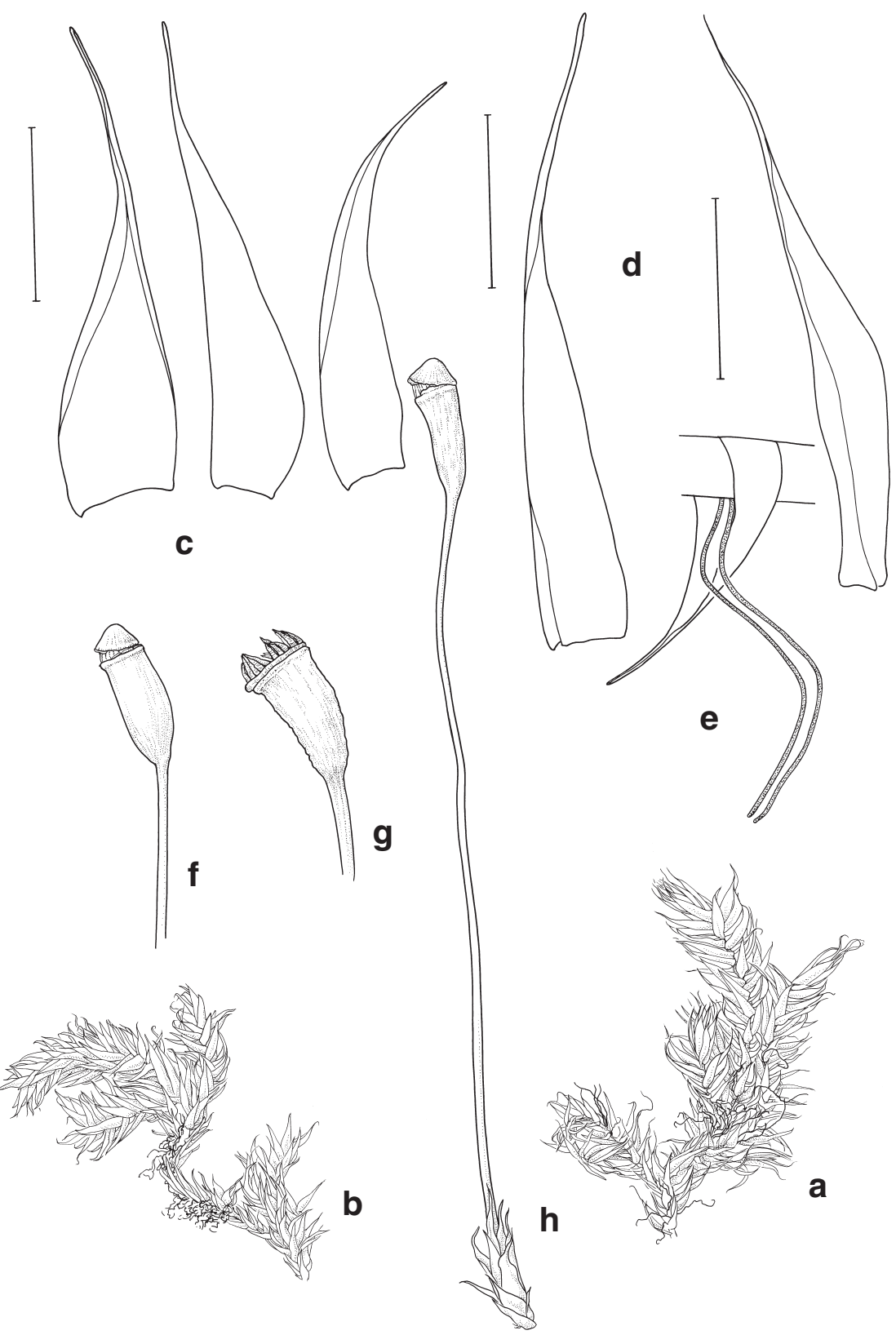

Fig. 3. Drawings of type specimens. a, habit of isotype of Hypnum terrae-novae var. australe (NY); b, habit of holotype of Isopterygium acuminatum (HO); c, branch leaves of $H$. terraenovae var. australe; d, branch leaves of I. acuminatum; e, stem, leaf and axillary rhizoids; f, capsule with operculum of $H$. terrae-novae var. australe; g, capsule showing peristome of $H$. terrae-novae var. australe; $\mathbf{h}$, sporophyte showing perichaetial leaves and capsule of isotype of $I$. limatum (NY). (a, b, f, g, h drawn by C. Wardrop, c, d, e by H. Ramsay). Scale bars: 0.5 mm for leaves, $1 \mathrm{~mm}$ for other drawings. 
Beilschmiedia tawa, Carpodetus serratus, Melicytus macrophyllus and Myrsine australis. It is apparently more common on the South Island than the North Island and ranges from near sea level to c. $1650 \mathrm{~m}$ (but is common below c. $700 \mathrm{~m}$ only from Canterbury southward). Figs 5, 6.

In Scott and Stone (1976), Lewinsky suggested that Isopterygium acuminatum from Tasmania was merely a growth form of Isopterygium limatum. We have examined type material (Ramsay \& Seur 1994) of I. acuminatum as well as many Tasmanian collections and we concur with Lewinsky's suggestion.

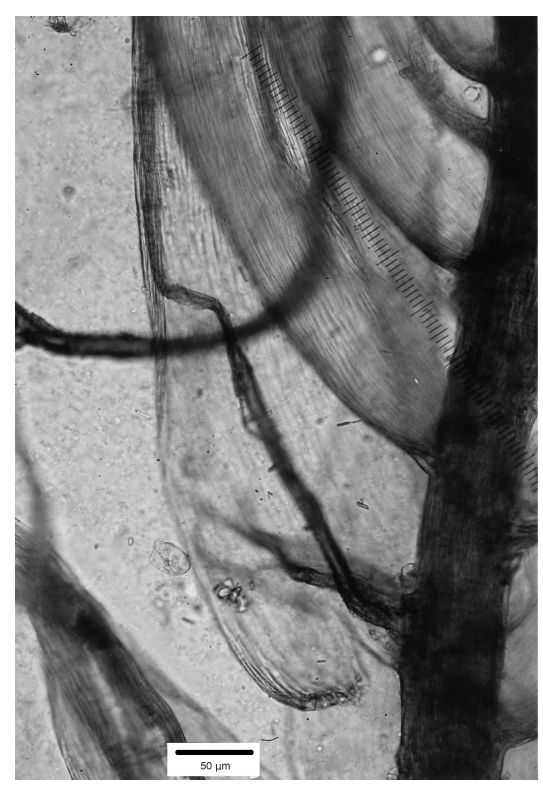

Fig. 4. Austrohondaella limata showing rhizoids in axil of lower stem leaf. (from R.D. Seppelt 12897 in NICH; photograph by Z. Iwatsuki).

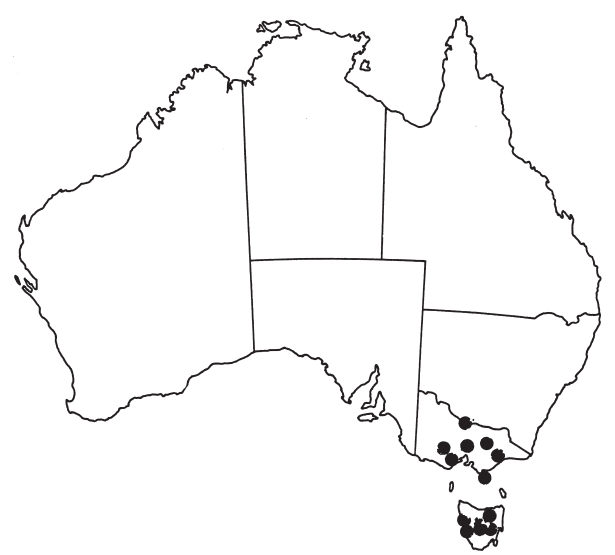

Fig 5. Australian distribution of Austrohondaella limata. 


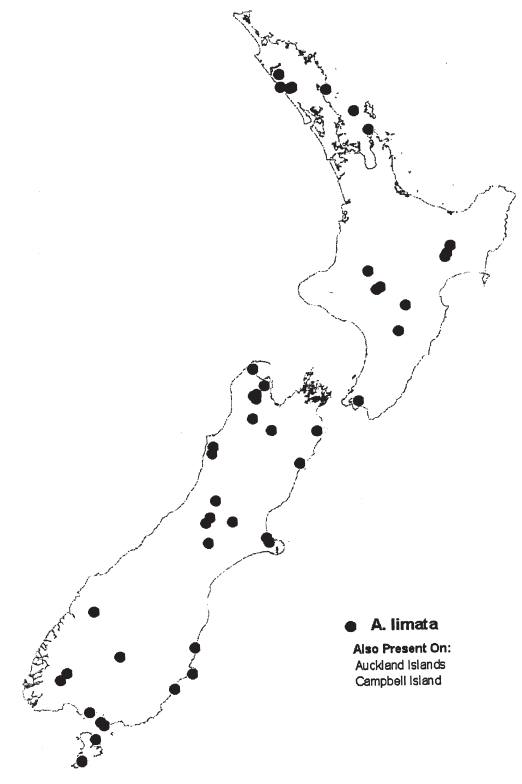

Fig. 6. New Zealand distribution of Austrohondaella limata.

Selected Specimens: Australia. New South Wales: Yarrangobilly Caves, W.W. Watts 8822, 8823, 8807 (NSW). Victoria: Sabine Falls track, Angahook-Lorne state forest, $19 \mathrm{~km} \mathrm{NE}$ of Apollo Bay, H. Streimann 58986 (NICH, CANB); Bulga National Park, Lyrebird-Ash Tracks, H. Streimann 51621 (NICH, CANB); Mt Cole State Forest, $27 \mathrm{~km}$ E of Arrarat, H. Streimann 54841 (CANB); Maits Rest, Ocean Road 10 km W of Apollo Bay, H. Streimann 58644 (CANB). Tasmania: Williamsford - Montezuma Falls Track, H. Streimann 59570A (NICH, CANB, HO); North Dundas, W.A. Weymouth 3037 (HO); Mt Rumney, R.A. Bastow 199 (HO); Western Tiers, northern side of Projection Bluff, R.D. Seppelt 12897 (NICH, HO); Lake Dobson Rd, Mt Field NP, D.H. Vitt 29139 \& H.P. Ramsay, (CANB, HO); Pipelma track, Mt Wellington, A. V. Ratkowsky H292 (CANB, HO); Roger River 6 km SW of Trowatta, A. Moscal 10572 (CANB, HO). Macquarie Island: Green Gorge, R.D. Seppelt 14306 (NICH, CHR 413613); Prion Lake, R.D. Seppelt 011342 (NICH ); Douglas Point, R.D. Seppelt $12445(\mathrm{NICH})$.

New Zealand: North Island: Maunganui Bluff, A.J. Fife 10705 (CHR 570024); Coromandel Peninsula, Moehau, L.B. Moore 254 (CHR 593700A, WELT M15107); Gisborne, Lake Waikaremoana, Panekiri Range, G.O.K. Sainsbury s.n., 3 Mar 1940, (WELT M015126); Central Volcanic Plateau, Mt. Hauhungatahi, J.K. Bartlett A11 (NICH); Tongariro National Park, southwest flank of Mt. Ruapehu, Blyth Hut track, A.J. Fife 9803 (CHR 512033); NW Ruahine Range, Ohutu Ridge, B.H. Macmillan 92/8 (CHR 482367). South Island: Mt. Burnett, near Collingwood, A.J. Fife 11734 (CHR 581481); N.W. Nelson, Cobb Valley, J.K. Bartlett A7 (NICH); N.W. Nelson, Arthur Range, Mt. Hoary Head, J.K. Bartlett 19388 (NICH); Gouland Downs, Big River, M.J.A. Simpson 7278 (CHR 106958); Mt Owen, Sanctuary Basin, A.J. Fife 5061 (CHR 103645); Marlborough, Woodside Creek, W. Martin 593 (CHR 587227); Canterbury, Arthurs Pass National Park, Bealey River Gorge, V.O. Heinz 96/29 \& B.H. Macmillan (CHR 510127, NICH); Joyces Creek, tributary of Waimakariri River, B.H. Macmillan 75/143 (CHR 264840); Westland, Kelly's Hill (=Kelly Range), S. Berggren 2805 (NICH, WELT M1050); Otago, Otago 
Peninsula, near Larnach's [Castle], J. Child 6212 (CHR 429281, NICH); Dunedin, Tysons Wall, Leith Valley, J. Child s.n. (NICH 300228); Dunedin area, Swampy Summit, W.B. Schofield 49995 (NICH); Akatore Stream, south of Dunedin, K.W. Allison 1414 (CHR 577752); Tautuku Bay, Lake Wilkie, W.B. Schofield 49432 (NICH); Southland, Garvie Mountains, above Lake Scott, D. Glenny 6393 (CHR 509918); Bluff-Invercargill - Winton, S. Berggren s.n., 1874 (NICH 278551). Stewart Island. Port Pegasus, W. Martin 275.3 (CHR 577758); summit of Tin Range, W. Martin 275.20 (CHR 593701). Auckland Islands. Auckland Island, Hanfield Inlet, D.H. Vitt 10176 (CHR 448072). Campbell Island. Perseverance Harbour, D.H. Vitt 2945 (CHR 577763).

\section{Acknowledgments}

We are extremely indebted to the Directors of the Herbarium of the New York Botanical Garden NY and the Tasmanian Herbarium HO for loans of the type specimens. We acknowledge NICH, HO, CANB, CHR, WELT help with access to specimens and MEL for distribution data. We also thank Dr. Peter Wilson for his kind assistance in preparing the Latin description. Assistance with illustrations by Rebecca Wagstaff (CHR) and Catherine Wardrop (NSW) is kindly acknowledged. Photographs were prepared by Zen Iwatsuki (NICH). Maps were prepared by Sue Gibb and Jane Cruickshank (CHR) for New Zealand and Helen Ramsay (NSW) for Australia. Work by A.J. Fife was supported by the N.Z. Foundation for Research, Science and Technology through the Defining New Zealand's Terrestrial Biota OBI. The Australian investigations are a contribution towards the Flora of Australia studies on bryophytes (mosses).

\section{References}

Beever J, Allison KW \& Child J (1992) The mosses of New Zealand. (University of Otago Press: Dunedin)

Hooker JD (1847) The botany of the Antarctic Voyage of H.M. Discovery Ships Erebus and Terror in the years 1839-1843. I. Flora Antarctica, part I. Botany of Lord Auckland's group and Campbell's Island. (Reeve: London)

Ireland RR (1991) A preliminary study of the moss genus Isopterygium in Latin America. Caldasia 16(78): 265-276.

Iwatsuki Z (1970) A revision of Plagiothecium and its related genera from Japan and her adjacent regions. Journal of the Hattori Botanical Laboratory 33: 331-380.

Iwatsuki Z (1987) Notes on Isopterygium Mitt (Plagiotheciaceae). Journal of the Hattori Botanical Laboratory 63: 445-451.

Iwatsuki Z \& Ramsay HP (2009) The genera Isopterygium Mitt. (Bryopsida, Hypnaceae) and Isopterygiopsis (Hedw.) Z.Iwats. (Plagiotheciaceae) in Australia. Telopea 12(3): 371-384.

Noguchi A (1994) Illustrated moss flora of Japan, part 5: (Hattori Botanical Laboratory: Nichinan)

Ramsay HP \& Seur J (1994) Register of type specimens of mosses in Australian herbaria. Flora of Australia supplementary series No 2. (Australian Biological Resources Study: Canberra)

Sainsbury GOK (1955) A handbook of the New Zealand mosses. Bulletin of the Royal Society of New Zealand 5: 1-490.

Sakurai K (1938) Beobachtungen über japanische Moosflora XVI. Botanical Magazine (Tokyo) 52: 129-135.

Scott GAM \& Stone IG (1976) The mosses of southern Australia. (Academic Press: London)

Seppelt RD (2004) The moss flora of Macquarie Island. (Australian Antarctic Division: Kingston, Tasmania) 